\title{
DAMPAK POPULASI DAN MOBILITAS PERKOTAAN TERHADAP PENYEBARAN PANDEMI COVID-19 DI JAKARTA
}

\author{
Rizki Adriadi Ghiffari ${ }^{1}$
}

'Departemen Geografi Pembangunan, Fakultas Geografi, Universitas Gadjah Mada

Jl. Kaliurang, Sekip Utara, Sinduadi, Kec. Mlati, Kab. Sleman, Daerah Istimewa Yogyakarta

Email corresponding: rizki.adriadi.g@ugm.ac.id

\begin{tabular}{|c|c|c|}
\hline Dikirimkan: & Diterima: & Diterbitkan: \\
$20-06-2020$ & $24-06-2020$ & $27-07-2020$ \\
\hline
\end{tabular}

\begin{abstract}
The Covid-19 disease outbreak has spread to more than 200 countries, including Indonesia. Epicenter of the spread of the disease is in big cities that have been designated as local transmission, including the city of Jakarta. In addition to the ability of virus transmission, the spread of infectious diseases directly is also influenced by the characteristics of the population and human mobility as a breeding ground for viruses. Based on the results of the correlation test, it was found that mobility within the city and external mobility, had an intermediate effect on the spread of COVID-19 disease. While the human development index, population growth, poor population, and vulnerable age variables also have a low impact on the spread of this disease. The ability to detect and respond to large-scale disease outbreaks is needed, and effective population mobility restrictions are needed to control the spread of this disease.
\end{abstract}

Key words: Urban Demographic, Urban Mobility, Covid-19 Pandemic

\begin{abstract}
Abstrak
Wabah penyakit Covid-19 telah menyebar ke lebih dari 200 negara, termasuk Indonesia. Episentrum penyebaran penyakit berada di kota-kota besar yang telah ditetapkan sebagai transmisi lokal, diantaranya Kota Jakarta. Selain kemampuan penularan virus, penyebaran penyakit menular langsung juga dipengaruhi oleh karakteristik populasi dan mobilitas manusia sebagai inang perkembangbiakan virus. Berdasarkan hasil uji korelasi didapatkan bahwa mobilitas di dalam kota dan mobilitas dari luar kota, berpengaruh dalam tingkat menengah terhadap penyebaran penyakit COVID-19. Sedangkan variabel indeks pembangunan manusia, pertumbuhan penduduk, penduduk usia rentan, penduduk miskin juga berpengaruh secara rendah terhadap penyebaran penyakit ini. Diperlukan kemampuan mendeteksi dan merespon wabah penyakit skala besar, serta pembatasan mobilitas penduduk yang efektif untuk dapat mengendalikan penyebaran penyakit ini.
\end{abstract}

Kata Kunci: Karakteristik Demografi, Mobilitas Penduduk, Pandemi Covid-19 


\section{PENDAHULUAN}

COVID-19 telah menjadi wabah penyakit dengan tingkat penyebaran dan keparahan yang mengkhawatirkan. Oleh karena itu wabah penyakit ini ditetapkan menjadi pandemi global oleh WHO sejak tanggal 11 Maret 2020. Bukti dari gelombang kedua penyebaran penyakit ini dengan berkembang pesatnya kasus konfirmasi baru di luar China, yakni pada negara-negara di eropa, amerika utara, asia, dan timur tengah (Bedford et al., 2020).

WHO menetapkan empat skenario dalam penilaian risiko nasional terhadap penyebaran COVID-19, yakni: negara-negara tanpa kasus konfirmasi positif, kasus pertama, klaster pertama, dan negara-negara dengan transmisi lokal. Untuk itu, setiap negara perlu meningkatkan tindakan kesiapsiagaan dan respon tanggap darurat yang cepat dan memadai, termasuk kesiapan infrastruktur kesehatan dan interaksi sosial masyarakat. Indonesia telah masuk pada skenario ke-4 dengan ditemukannya kasus konfirmasi positif akibat transmisi lokal di beberapa wilayah, termasuk Kota Jakarta.

Penyebaran penyakit menular seperti pandemic COVID-19 dipengaruhi oleh interaksi anatara dua fakor utama, yakni kemampuan penularan pantogen yang bertanggung jawab atas infeksi dan karakteristik populasi manusia sebagai inang dalam perkembangbiakan pantogen tersebut (Merler \& Ajelli, 2010).

Penelitian ini bertujuan menguji pengaruh faktor-faktor populasi dan mobilitas penduduk terhadap tingkat penyebaran wabah penyakit COVID-19 di wilayah perkotaan Provinsi DKI Jakarta.

\section{METODOLOGI PENELITIAN}

Penyebaran penyakit menular COVID-19, selain dipengaruhi oleh faktor spesifik patogennya, juga dipengaruhi oleh struktur populasi dan mobilitas penduduk sebagai kerentanan sosial dalam menghadapi wabah penyakit, antara lain: kepadatan penduduk, kemiskinan, aktivitas sosial ekonomi di luar rumah, dan perjalanan antar kota (Sands dkk., 2016) (Farmer, 1996). Selain itu, keberadaan permukiman kumuh dengan kebersihan lingkungan dan sanitasi yang buruk juga dapat meningkatkan indeks kerentanan terhadap wabah penyakit ini (Toole \& Waldman, 1990).

Penelitian ini dilakukan dengan menguji korelasi pearson antara faktor-faktor demografi dan mobilitas penduduk terhadap pertambahan jumlah kasus konfirmasi positif di wilayah perkotaan Indonesia. Metode korelasi pearson digunakan karena dapat menggambarkan kekuatan korelasi linear antara 2 variabel yang diasumsikan memiliki hubungan monotonik dan memiliki skala data ratio atau interval (Lee Rodgers \& Alan Nice Wander, 1988), yakni setiap variabel independen dari faktor-faktor demografi dan mobilitas penduduk terhadap jumlah konfirmasi kasus positif sebagai variabel dependen.

Data penelitian didapatkan dari hasil survei sekunder instansional. Data demografi didapatkan dari dokumen Provinsi Dalam Angka yang diterbitkan Badan Informasi Statistika, data mobilitas penduduk didapatkan dari hasil tracking perangkat ponsel yang didapatkan dari LOTaDATA, sedangkan data konfirmasi positif didapatkan dari data yang dipublikasi melalui web oleh Gugus Tugas COVID-19 di daerah.

Studi kasus dilakukan pada Kota Jakarta sebagai kota terbesar di Indonesia yang menjadi episentrum penyebaran penyakit COVID-19 dengan konfirmasi kasus transmisi lokal.

\section{HASIL PENELITIAN DAN PEMBAHASAN Perkembangan Pandemi COVID-19 di Jakarta}

Pandemi COVID-19 dimulai di Indonesia sejak teridentifikasi kasus konfirmasi positif pertama dan kedua pada tanggal 3 Maret 2020. Berdasarkan Riono dalam Detikcom, (2020), kasus penularan pertama di Indonesia diperkirakan terjadi sekitar akhir januari - awal februari, hal ini mengacu pada data jumlah pasien gejala COVID-19 di beberapa fasilitas kesehatan, tingginya jumlah penerbangan dari dan ke Wuhan, serta belum tersedianya pemeriksaan kesehatan yang memadai di bandara, sehingga masih memungkinkan lolosnya orang tanpa gejala atapun yang masih dalam masa inkubasi virus. Hingga 31 mei 2020, terdapat 7.272 kasus positif Covid-19 di Jakarta yang tersebar di seluruh kecamatan. Jumlah kasus positif terbesar berada di Kecamatan Tanah Abang, sebesar 337 kasus, dimana pada wilayah tersebut, terdapat lebih dari 2 jiwa positif Covid-19 pada setiap 1000 penduduk. Wilayah dengan konsentrasi kasus positif terbesar kedua adalah Kecamatan Menteng, Senen, Cempaka Putih, dan Pademangan, dimana pada wilayah tersebut terdapat lebih dari 1 jiwa positif Covid-19 pada setiap 1000 penduduk. 
Tabel 1. Jumlah Konfirmasi Positif Covid-19 di Jakarta (Hingga 31 Mei 2020)

\begin{tabular}{|c|c|c|c|}
\hline Kota & Kecamatan & Jumlah Kasus Positif & $\begin{array}{l}\text { Jumlah Kasus Positif } \\
\text { (Per } 1000 \text { Penduduk) }\end{array}$ \\
\hline \multirow{8}{*}{ Jakarta Pusat } & Tanah Abang & 337 & 2.28 \\
\hline & Menteng & 73 & 1.07 \\
\hline & Senen & 118 & 1.21 \\
\hline & Johar Baru & 70 & 0.58 \\
\hline & Cempaka Putih & 94 & 1.10 \\
\hline & Kemayoran & 132 & 0.58 \\
\hline & Sawah Besar & 92 & 0.91 \\
\hline & Gambir & 49 & 0.62 \\
\hline \multirow{6}{*}{ Jakarta Utara } & Penjaringan & 179 & 0.57 \\
\hline & Pademangan & 186 & 1.10 \\
\hline & Tanjung Priok & 291 & 0.70 \\
\hline & Koja & 128 & 0.37 \\
\hline & Kelapa Gading & 118 & 0.82 \\
\hline & Cilincing & 94 & 0.22 \\
\hline \multirow{10}{*}{ Jakarta Timur } & Pasar Rebo & 55 & 0.25 \\
\hline & Ciracas & 63 & 0.21 \\
\hline & Cipayung & 69 & 0.24 \\
\hline & Makasar & 68 & 0.33 \\
\hline & Kramat Jati & 148 & 0.50 \\
\hline & Jatinegara & 147 & 0.53 \\
\hline & Duren Sawit & 252 & 0.63 \\
\hline & Cakung & 123 & 0.23 \\
\hline & Pulogadung & 140 & 0.53 \\
\hline & Matraman & 137 & 0.90 \\
\hline \multirow{8}{*}{ Jakarta Barat } & Kembangan & 130 & 0.40 \\
\hline & Kebon Jeruk & 184 & 0.49 \\
\hline & Palmerah & 176 & 0.86 \\
\hline & Grogol Petamburan & 161 & 0.67 \\
\hline & Tambora & 133 & 0.55 \\
\hline & Taman Sari & 103 & 0.93 \\
\hline & Cengkareng & 138 & 0.23 \\
\hline & Kalideres & 122 & 0.26 \\
\hline \multirow{10}{*}{ Jakarta Selatan } & Jagakarsa & 95 & 0.24 \\
\hline & Pasar Minggu & 114 & 0.37 \\
\hline & Cilandak & 94 & 0.46 \\
\hline & Pesanggrahan & 82 & 0.37 \\
\hline & Kebayoran Lama & 135 & 0.44 \\
\hline & Kebayoran Baru & 71 & 0.49 \\
\hline & Mampang Prapatan & 57 & 0.39 \\
\hline & Pancoran & 64 & 0.41 \\
\hline & Tebet & 132 & 0.62 \\
\hline & Setia Budi & 67 & 0.47 \\
\hline
\end{tabular}

Sumber: Dinas Kesehatan Provinsi DKI Jakarta, 2020

\section{Struktur Populasi Penduduk}

Sebagai kota terbesar sekaligus ibu kota Indonesia, Jakarta menempati urutan pertama sebagai kota terpadat di Indonesia, dengan kepadatan rata-rata $18.191,65 \mathrm{Jiwa} / \mathrm{Km}^{2}$. Konsentrasi penduduk yang tinggi, terutama di bagian pusat kota yang memiliki permukiman informal yang padat, dapat menjadi episentrum penularan penyakit dan mempercepat penyebaran patogen (Neiderud, 2015). Selain itu, kesenjangan sosial dan kemiskinan juga dapat meningkatkan kerentanan individu terhadap infeksi secara signifikan (Farmer, 1996). Oleh karena itu, selain kepadatan penduduk, variabel lain yang diukur sebagai karakteristik populasi yang berpengaruh terhadap penyebaran penyakit menular adalah rasio jenis kelamin, persentase penduduk usia rentan, persentase penduduk miskin, dan indeks pembangunan manusia (Sands dkk., 2016). Struktur populasi penduduk DKI Jakarta ditampilkan melalui Tabel 2. 
Tabel 2. Struktur Penduduk Provinsi DKI Jakarta

\begin{tabular}{|c|c|c|c|c|c|}
\hline Kota & Kecamatan & $\begin{array}{c}\text { Kepadatan } \\
\text { Pendududuk } \\
\text { (Jiwa/Km²) }\end{array}$ & $\begin{array}{l}\text { Rasio Jenis } \\
\text { Kelamin }\end{array}$ & $\begin{array}{c}\text { Penduduk Usia } \\
\text { Rentan } \\
(\%) \\
\end{array}$ & $\begin{array}{c}\text { Penduduk } \\
\text { Miskin } \\
(\%) \\
\end{array}$ \\
\hline \multirow{8}{*}{ Jakarta Pusat } & Tanah Abang & $15,891.00$ & 101.52 & 29.06 & 3.59 \\
\hline & Menteng & $10,477.00$ & 95.35 & 29.06 & 3.59 \\
\hline & Senen & $23,122.00$ & 97.57 & 29.06 & 3.59 \\
\hline & Johar Baru & $50,630.00$ & 100.2 & 29.06 & 3.59 \\
\hline & Cempaka Putih & $18,227.00$ & 103.13 & 29.06 & 3.59 \\
\hline & Kemayoran & $31,610.00$ & 100.08 & 29.06 & 3.59 \\
\hline & Sawah Besar & $16,389.00$ & 95.17 & 29.06 & 3.59 \\
\hline & Gambir & $10,347.00$ & 97.29 & 29.06 & 3.59 \\
\hline \multirow{6}{*}{ Jakarta Utara } & Penjaringan & $7,733.00$ & 96.96 & 29.17 & 5.02 \\
\hline & Pademangan & $13,992.00$ & 102.93 & 29.17 & 5.02 \\
\hline & Tanjung Priok & $17,499.00$ & 99.42 & 29.17 & 5.02 \\
\hline & Koja & $25,844.00$ & 100.76 & 29.17 & 5.02 \\
\hline & Kelapa Gading & $10,690.00$ & 89.32 & 29.17 & 5.02 \\
\hline & Cilincing & $10,714.00$ & 96.51 & 29.17 & 5.02 \\
\hline \multirow{10}{*}{ Jakarta Timur } & Pasar Rebo & $17,040.00$ & 100.66 & 30.06 & 3.12 \\
\hline & Ciracas & $18,680.00$ & 100.79 & 30.06 & 3.12 \\
\hline & Cipayung & $9,920.00$ & 100.74 & 30.06 & 3.12 \\
\hline & Makasar & $9,360.00$ & 99.36 & 30.06 & 3.12 \\
\hline & Kramat Jati & $22,930.00$ & 99.43 & 30.06 & 3.12 \\
\hline & Jatinegara & $26,920.00$ & 106.55 & 30.06 & 3.12 \\
\hline & Duren Sawit & $17,640.00$ & 97.7 & 30.06 & 3.12 \\
\hline & Cakung & $12,720.00$ & 105.08 & 30.06 & 3.12 \\
\hline & Pulogadung & $17,050.00$ & 98.59 & 30.06 & 3.12 \\
\hline & Matraman & $31,110.00$ & 100.21 & 30.06 & 3.12 \\
\hline \multirow{8}{*}{ Jakarta Barat } & Kembangan & $13,557.00$ & 101.23 & 28.59 & 3.39 \\
\hline & Kebon Jeruk & $21,045.00$ & 100.62 & 28.59 & 3.39 \\
\hline & Palmerah & $27,374.00$ & 95.56 & 28.59 & 3.39 \\
\hline & Grogol Petamburan & $24,028.00$ & 105.62 & 28.59 & 3.39 \\
\hline & Tambora & $44,711.00$ & 92.18 & 28.59 & 3.39 \\
\hline & Taman Sari & $14,259.00$ & 100.57 & 28.59 & 3.39 \\
\hline & Cengkareng & $22,325.00$ & 96.17 & 28.59 & 3.39 \\
\hline & Kalideres & $15,337.00$ & 97.47 & 28.59 & 3.39 \\
\hline \multirow{10}{*}{ Jakarta Selatan } & Jagakarsa & $16,154.95$ & 100.90 & 29.08 & 3.14 \\
\hline & Pasar Minggu & $14,245.11$ & 100.65 & 29.08 & 3.14 \\
\hline & Cilandak & $11,156.18$ & 96.06 & 29.08 & 3.14 \\
\hline & Pesanggrahan & $17,506.23$ & 100.66 & 29.08 & 3.14 \\
\hline & Kebayoran Lama & $18,464.07$ & 98.74 & 29.08 & 3.14 \\
\hline & Kebayoran Baru & $11,138.35$ & 98.41 & 29.08 & 3.14 \\
\hline & Mampang Prapatan & $19,057.81$ & 105.03 & 29.08 & 3.14 \\
\hline & Pancoran & $18,240.13$ & 101.36 & 29.08 & 3.14 \\
\hline & Tebet & $23,419.11$ & 98.82 & 29.08 & 3.14 \\
\hline & Setia Budi & $16,080.47$ & 101.01 & 29.08 & 3.14 \\
\hline
\end{tabular}

Sumber: Badan Pusat Statistika DKI Jakarta, 2020

Berdasarkan data dari dokumen Provinsi DKI Jakarta Dalam Angka Tahun 2020 dan Kecamatan Dalam Angka Tahun 2020 (Tabel 2), wilayah dengan kepadatan penduduk tertinggi adalah Kecamatan Johar Baru di Jakara Pusat $(50.630$ Jiwa/ $/ \mathrm{Km}^{2}$ ) dan Kecamatan Tambora di Jakarta Barat (44.711 Jiwa/ $/ \mathrm{Km}^{2}$ ). Provinsi DKI Jakarta dengan rata-rata kepadatan penduduk sangat tinggi $\left(18.920 \quad \mathrm{Km}^{2}\right)$ menjadikan ancaman penyebaran virus dalam fase transmisi lokal.
Sementara dilihat dari variabel lainnya, jumlah penduduk miskin relatif rendah, namun jumlah penduduk usia rentan relatif tinggi. persentase penduduk miskin tertinggi terdapat di Kota Jakarta Utara, sedangkan persentase penduduk usia rentan $(<15$ tahun dan $>65$ tahun) tertinggi di Kota Jakarta Timur. Tindakan perlindungan terhadap penduduk usia rentan diperlukan untuk mencegah melonjaknya jumlah positif dengan keadaan serius yang membutuhkan perawatan 
intensif yang melampaui kapasitas pelayanan rumah sakit.

\section{Karakteristik Mobilitas Penduduk}

Selama masa pandemi Covid-19, sejak diumumkannya kasus pertama di Indonesia pada tanggal 3 Maret 2020, telah terjadi penurunan aktivitas perjalanan masyarakat di perkotaan.

Anjuran Physical Distancing Di DKI Jakarta telah mulai diterapkan sejak tanggal 14 Maret 2020, dibutikan melalui data mobilitas penduduk di beberapa fasilitas umum seperti fasilitas perdagangan dan jasa, fasilitas transportasi, perkantoran, dan rekreasi, yang ditampilkan melalui Gambar 1. Penurunan jumlah pengguna transportasi publik dimulai tanggal 13 Maret 2020, dan mencapai puncaknya sebesar $-79 \%$ dari kondisi normal sejak 10 April 2020, semenjak diberlakukannya PSBB yang salah satu aturannya adalah pembatasan sementara beberapa moda transportasi publik melalui perubahan jadwal operasional dan jumlah armada yang dioperasikan. Kegiatan perkantoran mulai menerapkan Work from Home (WfH) sejak 16 Maret 2020, yang juga mencapai puncaknya (73\%) pada saat dimulainya PSBB tahap I. Aktivitas masyarakat di taman kota dan tempat rekreasi lainnya mulai menurun tajam sejak 14 Maret 2020 dan mencapai puncaknya (-70\%) pada hari ke-3 penerapan PSBB Tahap 1. Aktivitas di pertokoan bahan pangan dan obat-obatan juga mengalami penurunan tajam, walaupun sempat mengalami lonjakan di saat menjelang PSBB Tahap 1 dan 2, namun tetap lebih rendah dari kondisi normal.

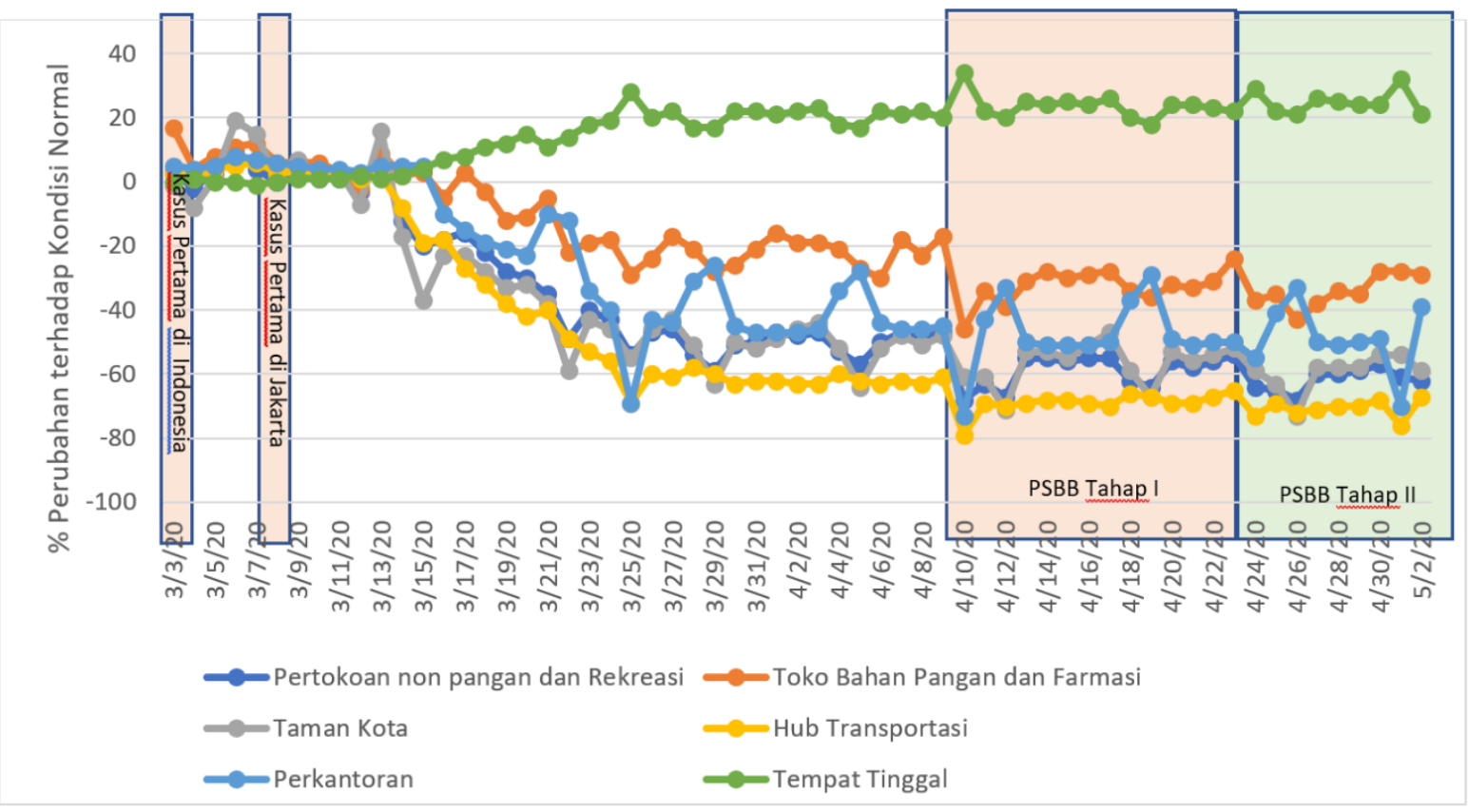

Gambar 1. Data Mobilitas Penduduk di DKI Jakarta Selama Masa Pandemi Covid-19 Sumber: Google Community, 2020

Berdasarkan data mobilitas penduduk di DKI Jakarta (Gambar 1) dapat diidentifikasi bahwa penurunan mobilitas penduduk jauh lebih tinggi saat kasus konfirmasi positif mengalami lonjakan lebih dari 200\% di tanggal 13 Maret 2020, dibandingkan pada saat penerapan PSBB. Diasumsikan, dampak psikologis dari peningkatan kasus konfirmasi positif yang signifikan lebih berpengaruh terhadap perilaku penduduk dalam menghindari perjalanan dan kerumunan.

Kemudian bila dicermati data pergerakan orang yang di tracking berdasarkan data telepon seluler, didapatkan data mobilitas orang pada setiap kota di Provinsi DKI Jakarta, yang dihimpun dari Kumar dkk., 2020, dan ditampilkan melalui Tabel 3. 
Tabel 3. Mobilitas Penduduk Pada Setiap Kota di Provinsi DKI Jakarta (Minggu Ke-1 Maret - Minggu Ke-3 April 2020)

\begin{tabular}{lrrrl}
\hline Kota & DALAM KOTA & $\begin{array}{c}\text { MOBILITAS }(\%) \\
\text { KE LUAR KOTA }\end{array}$ & DARI LUAR KOTA & $\begin{array}{l}\text { DAERAH DOMINAN } \\
\text { ASAL PERGERAKAN }\end{array}$ \\
\hline Jakarta Pusat & 86.66 & 7.74 & 70.33 & $\begin{array}{l}\text { Serang }(10,76 \%) \\
\text { Semarang }(10,64 \%)\end{array}$ \\
\hline Jakarta Utara & 51.00 & 6.30 & 3.94 & $\begin{array}{l}\text { Cilegon }(1,02 \%) \\
\text { Semarang }(0,52 \%)\end{array}$ \\
\hline Jakarta Timur & 53.72 & 8.48 & 29.55 & $\begin{array}{l}\text { Semarang }(5,37 \%) \\
\text { Cilegon }(1,72 \%)\end{array}$ \\
\hline Jakarta Barat & 48.00 & 6.31 & 9.33 & $\begin{array}{l}\text { Serang }(1,25 \%) \\
\text { Cilegon }(1,17 \%)\end{array}$ \\
\hline Jakarta Selatan & 39.00 & 16.06 & 4.89 & $\begin{array}{l}\text { Semarang }(0,69 \%) \\
\text { Yogyakarta }(0,42 \%)\end{array}$ \\
\hline
\end{tabular}

Berdasarkan data mobilitas penduduk hingga minggu ke-3 April 2020 (Tabel 3), pergerakan orang yang masuk ke DKI Jakarta Sebagian besar menuju Kota Jakarta Pusat dan Kota Jakarta Timur. Sebagian besar pergerakan orang berasal dari wilayah Jawa Barat dan Banten yang merupakan bagian dari Kawasan Megapolitan JABODETABEK, dimana Jakarta sebagai pusat/inti kawasan. Sementara pergerakan orang dari luar JABODETABEK yang terbesar berasal dari Kota Serang, Kota Semarang, dan Kota Cilegon. Kota Semarang tercatat memiliki kasus konfirmasi positif pertama pada tanggal 15 Maret 2020 dan pada Minggu ke-3 April 2020 meningkat menjadi 125 kasus (Dinas Kesehatan Kota Semarang, 2020).

\section{Analisis Korelasi}

Analisis korelasi dilakukan pada variabelvariabel independen dari faktor populasi dan mobilitas penduduk yang diujikan dengan variabel dependen berupa jumlah kasus positif per seribu jumlah penduduk. Pengujian ini bertujuan untuk menguji kekuatan hubungan sebab akibat dari setiap variabel independen terhadap penyebaran covid-19 di Kota Jakarta.

Nilai korelasi Pearson ( $r$ ) terbagi menjadi beberapa interval nilai, yakni: $0,1-0,39$ (korelasi lemah); 0,4 - 0,69 (korelasi menengah); 0,7 0,89 (korelasi kuat); dan 0,9-1,0 (korelasi sangat kuat) (Schober \& Schwarte, 2018). Korelasi (r) < 0,1 dapat diabaikan, atau pada beberapa penelitian ditetapkan angka $(r)<0,03$ sebagai nilai korelasi yang diabaikan (Nishimura et al., 2016).

Berdasarkan hasil uji korelasi, terdapat variabel jumlah penduduk $(r=-0,53)$, mobilitas dalam kota $(r=0,56)$, dan mobilitas luar kota $(r=$ 0,49 ) yang berkorelasi menengah terhadap penyebaran Covid-19 di Jakarta. Sementara variabel lainnya yang berkorelasi rendah terhadap penyebaran Covid-19 di Jakarta adalah pertumbuhan penduduk, indeks pembangunan manusia, mobilitas keluar kota, jumlah penduduk miskin, dan penduduk usia rentan. Secara rinci hasil uji korelasi ditampilkan melalui Tabel 4.

Tabel 4. Analisis Korelasi Setiap Variabel Terhadap Kasus Konfirmasi Positif

\begin{tabular}{clr}
\hline Faktor & \multicolumn{1}{c}{ Variabel Independen } & Nilai Korelasi \\
\hline & Jumlah Penduduk (2019) & $-0,53551$ \\
& Kepadatan Penduduk (Jiwa/Km2) & 0,04356 \\
& Rasio Jenis Kelamin & $-0,05968$ \\
Populasi Penduduk & Pertumbuhan Penduduk (\%) & $-0,30394$ \\
& Penduduk Usia Rentan (\%) & $-0,18377$ \\
& Jumlah Penduduk Miskin (\%) & 0,19091 \\
& Indeks Pembangunan Manusia & $-0,34293$ \\
\hline \multirow{3}{*}{ Mobilitas Penduduk } & Mobilitas Dalam Kota & 0,56614 \\
& Mobilitas Keluar Kota & $-0,25523$ \\
& Mobilitas Dari Luar Kota & 0,49558 \\
\hline
\end{tabular}

Sumber: Hasil Analisis Penulis, 2020 
Jumlah penduduk berkorelasi negatif terhadap penyebaran Covid-19 menunjukkan bahwa banyaknya jumlah penduduk dalam suatu kawasan tidak menjadi faktor utama yang mempengaruhi meluasnya pandemi ini, melainkan dari cara interaksi antar individu dalam komunitas. Sementara itu, berdasarkan variabel-variabel yang dianalisis, kontrol terhadap mobilitas penduduk dapat menjadi salah satu solusi pengendalian pandemi Covid-19. Dikarenakan mobilitas internal dalam kota maupun mobilitas masuk dari luar kota, sama-sama menunjukkan hubungan yang positif terhadap penambahan jumlah kasus konfirmasi positif di Provinsi DKI Jakarta.

Indeks pembangunan manusia, walaupun berkorelasi lemah, juga perlu diperhatikan dalam menghadapi bencana non alam sejenis di masa depan. Indek pembangunan manusia menggambarkan angka harapan hidup, tingkat Pendidikan, dan standar kelayakan hidup. Variabel ini juga memiliki pengaruh terhadap peyebaran wabah penyakit Covid-19, yang menggambarkan bahwa penduduk pada permukiman yang terpinggirkan, termasuk orang-orang yang tinggal di daerah kumuh perkotaan dan permukiman informal, kemungkinan menghadapi risiko yang tinggi terhadap mordibilitas dan mortalitas selama pandemi. Sementara standar kelayakan hidup yang rendah juga terkait dengan kondisi kebersihan lingkungan seperti kurangnya air bersih dan sanitasi yang memadai, juga akan memperkuat tingkat penularan, dan juga meningkatkan mordibitas dan mortalitas (Toole \& Waldman, 1990).

\section{KESIMPULAN DAN SARAN}

Penyebaran penyakit COVID-19 di Kota Jakarta lebih banyak dipengaruhi oleh faktor mobilitas penduduk, terutama mobilitas di dalam Kota Jakarta sendiri, dari salah satu bagian kota ke bagian kota yang lain. Hal ini disebabkan oleh tahapan penyebaran penyakit ini yang telah berlangsung melalui transmisi lokal, dimana banyak orang tanpa gejala / carrier yang masih terus menularkan virus di tengah-tengah masyarakat. Selain itu mobilitas penduduk dari luar Jakarta juga mempengaruhi tingkat infeksi, terutama yang berasal dari daerah yang telah terkonfirmasi memiliki kasus transmisi lokal.
Oleh karena itu penting adanya karantina wilayah yang efektif untuk mencegah meluasnya wilayah transmisi lokal yang disebabkan oleh mobilitas orang tanpa gejala. Untuk itu diperlukan upaya pemerintah melalui Lembaga yang ditunjuk dalam mendeteksi dan merespon wabah penyakit menular dalam skala besar. Serta kemampuan keuangan pemerintah untuk memobilisasi sumber daya keuangan untuk membayar biaya penanganan penyakit dan mengatasi guncangan ekonomi dari wabah (Oppenheim et al., 2019). Selain itu, Langkahlangkah pengendalian wabah penyakit berbasis masyarakat melalui peran komunitas dan institusi lokal pada tingkatan pemerintahan paling rendah juga diperlukan untuk mengawasi secara lebih detail dari pelaksanaan kebijakan yang tengah diambil oleh pemerintah.

\section{UCAPAN TERIMA KASIH}

Terima kasih kepada Departemen Geografi Pembangunan, Fakultas Geografi, Universitas Gadjah Mada, karena atas kesempatannya, penelitian ini dapat diselesaikan.

\section{DAFTAR PUSTAKA}

Badan Pusat Statistika DKI Jakarta. (2020). Provinsi DKI Jakarta Dalam Agka. Jakarta: Badan Pusat Statistika.

Bedford, J., Enria, D., Giesecke, J., Heymann, D. L., Ihekweazu, C., Kobinger, G., ... Wieler, L. H. (2020). COVID-19: towards controlling of a pandemic. The Lancet, 395(10229),

1015-1018. https://doi.org/10.1016/S01406736(20)30673-5

Detikcom. (2020, April 20). Ungkap Corona Masuk RI Sejak Januari , Pakar UI: Pemerintah Menyangkal Terus. Trans Media, pp. 1-6.

Dinas Kesehatan Kota Semarang. (2020). Data Informasi Coronavirus ( Covid-19) Kota Semarang, (April), 2020. Retrieved from https://siagacorona.semarangkota.go.id/h alaman/odppdpv2

Dinas Kesehatan Provinsi DKI Jakarta. (2020). Data Pemantauan COVID-19 DKI Jakarta Tanggal 31 Mei 2020. Jakarta.

Farmer, P. (1996). Social Inequalities and Emerging Infectious Diseases. Emerging Infectious Diseases, 2(4), 259-269. https://doi.org/10.3201/eid0204.960402 
Google Community. (2020). Google Community Mobility Report of Indonesia. Mountain View, California. Retrieved from

https://www.google.com/covid19/mobilit y/

Kumar, A., Holenweger, R., \& Martins, J. (2020). COVID-19 Aggregated movement patterns correlated to confirmed case counts of Indonesia. San Francisco. Retrieved from http://wwwhttps//citydash.ai/data_for_hu manity/public_health/indonesia

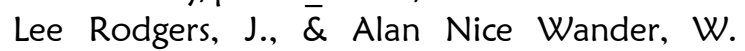 (1988). Thirteen ways to look at the correlation coefficient. American Statistician, 42(1), 59-66. https://doi.org/10.1080/00031305.1988.1 0475524

Merler, S., \& Ajelli, M. (2010). The role of population heterogeneity and human mobility in the spread of pandemic influenza. In Proceedings of The Royal Society (pp. 557-565). The Royal Society. https://doi.org/10.1098/rspb.2009.1605

Neiderud, C. J. (2015). How urbanization affects the epidemiology of emerging infectious diseases. African Journal of Disability, 5(1), 1-9. https://doi.org/10.3402/iee.v5.27060

Nishimura, A., Tabuchi, Y., Kikuchi, M., Masuda, R., Goto, K., \& lijima, T. (2016). The Amount of Fluid Given During Surgery That Leaks Into the Interstitium Correlates With Infused Fluid Volume and Varies Widely Between Patients. Anesthesia \& Analgesia, 123, 1. https://doi.org/10.1213/ANE.0000000000 001505

Oppenheim, B., Gallivan, M., Madhav, N. K., Brown, N., Serhiyenko, V., Wolfe, N. D., \& Ayscue, P. (2019). Assessing global preparedness for the next pandemic: Development and application of an Epidemic Preparedness Index. BMJ Global Health, 4(1), 1-9. https://doi.org/10.1136/bmjgh-2018001157

Sands, P., El Turabi, A., Saynisch, P. A., \& Dzau, V. J. (2016). Assessment of economic vulnerability to infectious disease crises. The Lancet, 388(10058), 2443-2448. https://doi.org/10.1016/S01406736(16)30594-3

Schober, P., \& Schwarte, L. A. (2018). Correlation coefficients: Appropriate use and interpretation. Anesthesia and Analgesia, 126(5), 1763-1768.
https://doi.org/10.1213/ANE.0000000000 002864

Toole, M. J., \& Waldman, R. J. (1990). Prevention of Excess Mortality in Refugee and Displaced Populations in Developing Countries. JAMA: The Journal of the American Medical Association, 263(24), 3296-3302.

https://doi.org/10.1001/jama.1990.03440 240086021 